\title{
Transport processes of copper and zinc in a highly eutrophic and meromictic lake
}

\author{
By Peter Baccini and Thomas Joller \\ Swiss Federal Institute for Water Resources and Water Pollution Control (EAWAG), Lake Research \\ Laboratory, Kastanienbaum, Switzerland
}

Manuscript received on 6 January $198 \mathrm{I}$

\begin{abstract}
Lake Baldegg was chosen to study the influence of a permanent anaerobic hypolimnion on the transport of copper and zinc. The evaluation of concentration variations in function of time and depth and the sedimentation rates lead to the conclusion that copper, in contrast to zinc, is sorbed additionally on newly formed iron particles at the $\mathrm{Fe}^{3+} / \mathrm{Fe}^{2+}$ interface and transported on the 'iron wheel'. A fiux scheme for the hypolimnic transport of copper is quantified in a one-dimensional diffusion model. By this the observed variations of concentration profiles can be explained.
\end{abstract}

\section{List of symbols}

$\mathrm{A}_{\mathrm{Z}} \quad$ Lake surface at depth $\mathrm{Z}\left[\mathrm{m}^{2}\right]$

c Copper to iron ratio (atomic numbers) in the newly formed particle at the $\mathrm{Fe}^{3+} / \mathrm{Fe}^{2+}$ interface

d Flux ratio of particulate autochthonous copper entering and leaving the hypolimnion

$\mathrm{DCu}_{\mathrm{E}} \quad$ Flux of dissolved copper from the epilimnion to the hypolimnion [mole $\mathrm{m}^{-2} \mathrm{~d}^{-1}$ ]

$\mathrm{DCu}_{\mathrm{s}} \quad$ Flux of dissolved copper from the sediment [mole $\left.\mathrm{m}^{-2} \mathrm{~d}^{-1}\right]$

$\mathrm{DFe}_{\mathrm{S}} \quad$ Flux of dissolved iron from the sediment $\left[\right.$ mole $\mathrm{m}^{-2} \mathrm{~d}^{-1}$ ]

$\mathrm{f}$

$\mathrm{J}$

Copper to iron ratio (atomic numbers) in the allochthonous particle

Source and sink function of chemical reactions [mole $\left.\mathrm{m}^{-3} \mathrm{~d}^{-1}\right]$

$k(Z) \quad$ Eddy diffusion coefficient at depth Z

$K_{1} \quad$ Reaction rate for the formation of new particulate copper at the $\mathrm{Fe}^{3+} / \mathrm{Fe}^{2+}$ interface $\left[\mathrm{d}^{-1}\right]$

$\mathrm{K}_{2} \quad$ Reaction rate for the redissolution of particulate organic copper in the hypolimnion [ $\left.\mathrm{d}^{-1}\right]$

n Copper to nitrogen ratio (atomic numbers) in the organic particle

$\mathrm{PN}_{\mathrm{E}} \quad$ Flux of organic particulate nitrogen entering the hypolimnion [mole $\mathrm{m}^{-2} \mathrm{~d}^{-1}$ ]

$\mathrm{PN}_{\mathrm{Epi}} \quad$ Concentration of particulate nitrogen in the epilimnion [mole $\mathrm{m}^{-3}$ ]

$\mathrm{DM} \quad$ Concentration of metal $\mathrm{M}\left[\mathrm{mole}^{-3}\right.$ ]

$\mathrm{PCu}_{\mathrm{A}} \quad$ Flux of alloch thonous particulate copper [mole $\left.\mathrm{m}^{-2} \mathrm{~d}^{-1}\right]$

$\mathrm{PCu}_{\mathrm{E}} \quad$ Flux of autochthonous particulate copper [mole $\mathrm{m}^{-2} \mathrm{~d}^{-1}$ ] entering the hypolimnion

$\mathrm{PCu}_{\mathrm{E}}^{\prime} \quad$ Flux of autochthonous particulate copper from the hypolimnion to the sediment

[ mole $\mathrm{m}^{-2} \mathrm{~d}^{-1}$ ]

$\mathrm{PCu}_{\mathrm{Fe}} \quad$ Concentration of particulate copper in the newly formed particle at the $\mathrm{Fe}^{3+} / \mathrm{Fe}^{2+}$ interface [mole $\mathrm{m}^{-2}$ ]

$\mathrm{PCu}_{0} \quad$ Concentration of particulate organic copper [mole $\left.\mathrm{m}^{-2}\right]$

$\mathrm{PFe}_{\mathrm{A}} \quad$ Flux of allochthonous particulate iron [mole $\mathrm{m}^{-2} \mathrm{~d}^{-1}$ ]

$\mathrm{PFe}_{\mathrm{Epi}} \quad$ Concentration of particulate iron in the epilimnion [mole $\mathrm{m}^{-3}$ ]

$\mathrm{PFe}_{\mathrm{D}} \quad$ Flux of newly formed particulate iron at the $\mathrm{Fe}^{3+} / \mathrm{Fe}^{2+}$ interface [mole m $\mathrm{m}^{-2} \mathrm{~d}^{-1}$ ] 
$\mathrm{PFe}_{\mathrm{H}} \quad$ Flux of particulate iron leaving the hypolimnion [mole $\mathrm{m}^{-2} \mathrm{~d}^{-1}$ ]

$\mathrm{S} \quad$ Index for sediment

TC Index for thermocline

$\mathrm{v}_{\mathrm{A}} \quad$ Mean sedimentation rate of allochthonous particles [m $\left.\mathrm{m}^{-1}\right]$

$V_{E} \quad$ Mean sedimentation of autochthonous organic particles entering the hypolimnion $\left[\mathrm{m} \mathrm{d}^{-1}\right]$

$v_{\mathrm{H}} \quad$ Sedimentation of newly formed particles at the $\mathrm{Fe}^{3+} / \mathrm{Fe}^{2+}$ interface $\left[\mathrm{m} \mathrm{d}^{-1}\right]$

\section{Introduction}

During the last decade a great number of investigations has given clear evidence that all lakes with human activities in their drainage area have experienced increased heavy metal loadings. Previous studies of ecological perturbations of aquatic systems by additional heavy metal input $[1,2]$ have led to the conclusion that copper and zinc are the two elements whose tolerance limits for Swiss running waters $(0.16$ and $3.1 \times 10^{-6} \mathrm{M}$, respectively) should be lowered in order to prevent toxic effects on plankton communities.

The regulation of the concentrations of the dissolved forms of copper and zinc in lakes is primarily due to the phytoplankton growth (Baccini $[3,4]$ ). In a first approximation the residence time of copper and zinc can be predicted if the production of biomass, the sedimentation rate and the hydraulic properties of the lake are known. This is true for holomictic systems under aerobic conditions.

Lake Baldegg, a meromictic lake in central Switzerland, was chosen to study the influence of a permanent anaerobic hypolimnion on the transport of copper and zinc within the lake.

\section{Methods}

Lake Baldegg is situated approximately $20 \mathrm{~km}$ to the north of the city of Lucerne. Its characteristics are resumed in table 1.

\subsection{Sample collection}

\subsection{Lake water}

Samples for the concentration profile of metals and the complementary parameters were drawn monthly in the middle of the lake from depths of $0,5,10,15,25,35,45$,

Table 1. Properties of Lake Baldegg.

Tabelle 1. Beschreibung des Baldeggersees.

\begin{tabular}{lr}
\hline Surface area/Oberfläche & $5.2 \mathrm{~km}^{2}$ \\
Length/Länge & $4.2 \mathrm{~km}$ \\
Width/Breite & $1.3 \mathrm{~km}$ \\
Mean depth/Mittlere Tiefe & $34 \mathrm{~m}$ \\
Maximum depth/Maximale Tiefe & $66 \mathrm{~m}$ \\
Drainage area/Einzugsgebiet & $74 \mathrm{~km}^{2}$ \\
Mean flow rate/Mittlere Zuflussrate & $1 \mathrm{~m}^{3} \mathrm{sec}^{-1}$ \\
Mean residence time of water/Mittlere Aufenthaltszeit des Wassers & $6 \mathrm{years}^{-1}$ \\
Primary production/Primärproduktion & $420 \mathrm{~g} \mathrm{C} \mathrm{m}^{-2} \mathrm{y}^{-1}$ \\
\hline
\end{tabular}


55, 65 and $66 \mathrm{~m}$ in Niskin bottles. The period of time observed went from 1 December 1976 to 22 November 1977.

\subsection{Sediments}

A sediment trap made of acryl resin (diameter $14 \mathrm{~cm}$, height $50 \mathrm{~cm}$ ) was installed in the middle of the lake at depth of $65.5 \mathrm{~m}(0.5 \mathrm{~m}$ above ground). The sediments were collected monthly.

\subsection{Chemical analysis}

The metals $\mathrm{Ca}, \mathrm{Mn}, \mathrm{Fe}, \mathrm{Cu}$ and $\mathrm{Zn}$ in lake water (TM = total metal, $\mathrm{DM}=$ dissolved metal, filtered through $0.45 \mu \mathrm{m}$ Millipore filter) and sediments were measured by atomic absorption spectroscopy. The experimental techniques were described in detail by Baccini et al. [4].

The complementary parameters were determined as follows:

- Sulfide spectrophotometrically (Strickland and Parsons [5]).

- Dissolved organic carbon with an UNOR apparatus.

- Particulate organic carbon with a DOHRMANN DC-50/52.

- $\mathrm{pH}$ and alkalinity with a combined glass electrode, titrating to $\mathrm{pH}=4.3$.

- Oxygen with Winkler's reagent.

- Particulate organic nitrogen and ammonium as described by Stadelmann [6].

-- Methane as described by Bossard [7].

\section{Results}

\subsection{Variation of Redox properties in function of time and depth}

The parameters oxygen, manganese, iron, ammonium, sulfide and methane were chosen to characterize the seasonal variation of the electron activity within a water column.

Below a depth of $25 \mathrm{~m}$ the lake is in an anaerobic state all year (fig. 1 ). During spring from March to May, an increased oxygen flux into the hypolimnion is observed where reduced forms of manganese (fig. 2), iron (fig.3) and sulfur (fig. 1) are oxydized. By this oxydation approximately $50 \%$ of the total quantity of manganese and iron in the water column is precipitated into the sediment (fig. 4). Redissolution of manganese begins already in April (fig. 2) and leads to a constant concentration profile in the hypolimnion (15-63 m) in early June (fig. 2). The redissolution of iron (fig. 3) and sulfide (fig. 1) starts in May. A constant concentration profile is reached at the end of August.

From a quantitative point of view the most important electron donators in the dissolved state are the species ammonium, methane and sulfide (fig. 5). The sum of their oxygen reducing capacity (4 moles of electrons per mole molecular oxygen) is presented in curve R. Only during spring time the lake has a slight excess of oxygen. In this comparison additional reducing capacities such as fractions of dissolved organic matter other than methane and of organic particles are not included. 


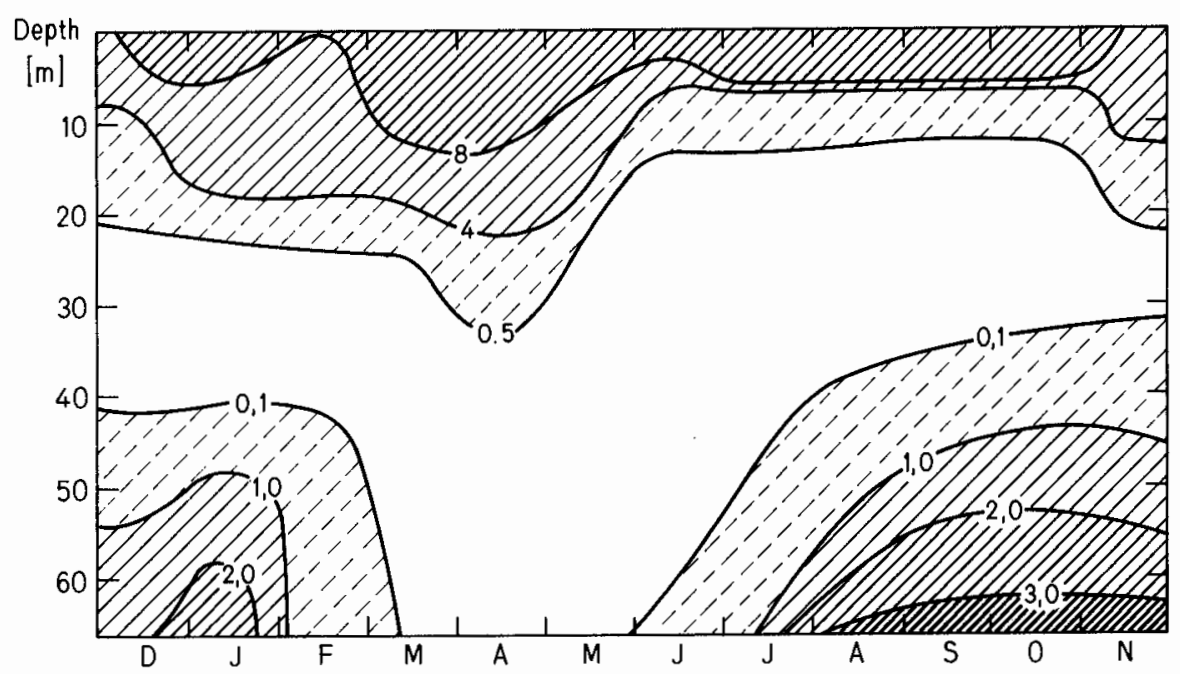

Figure 1. Isopleths of oxygen and sulfide $\left[\mathrm{mg} \mathrm{l}^{-1}\right]$ in Lake Baldegg, December 1976 to November 1977. Abb. 1. Sauerstoff- und Sulfid-Isoplethen im Baldeggersee.

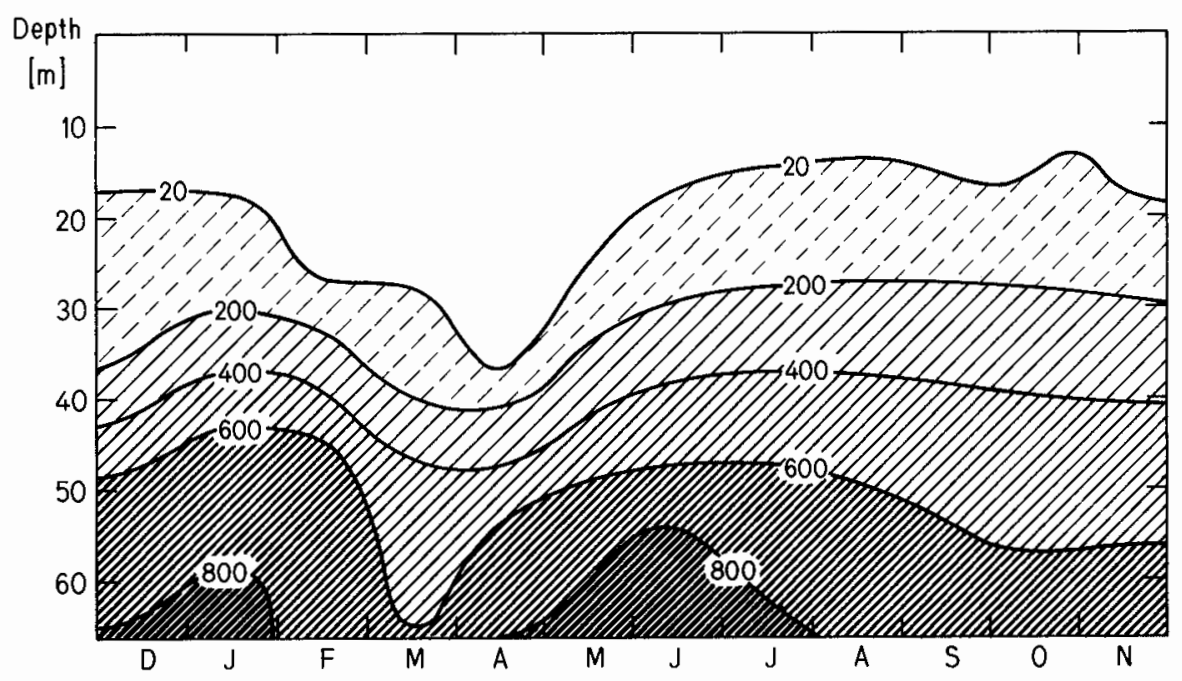

Figure 2. Isopleths of dissolved manganese $\left[10^{-8} \mathrm{M}\right]$.

Abb. 2. Isoplethen des gelösten Mangans.

In conclusion the hypolimnion of Lake Baldegg may be described as an aquatic system in which fluxes of oxydized iron and manganese in particulate forms to the sediment and fluxes of reduced dissolved forms from the sediment leads to the observed concentration profiles. The layers of equal concentration of the oxydized 


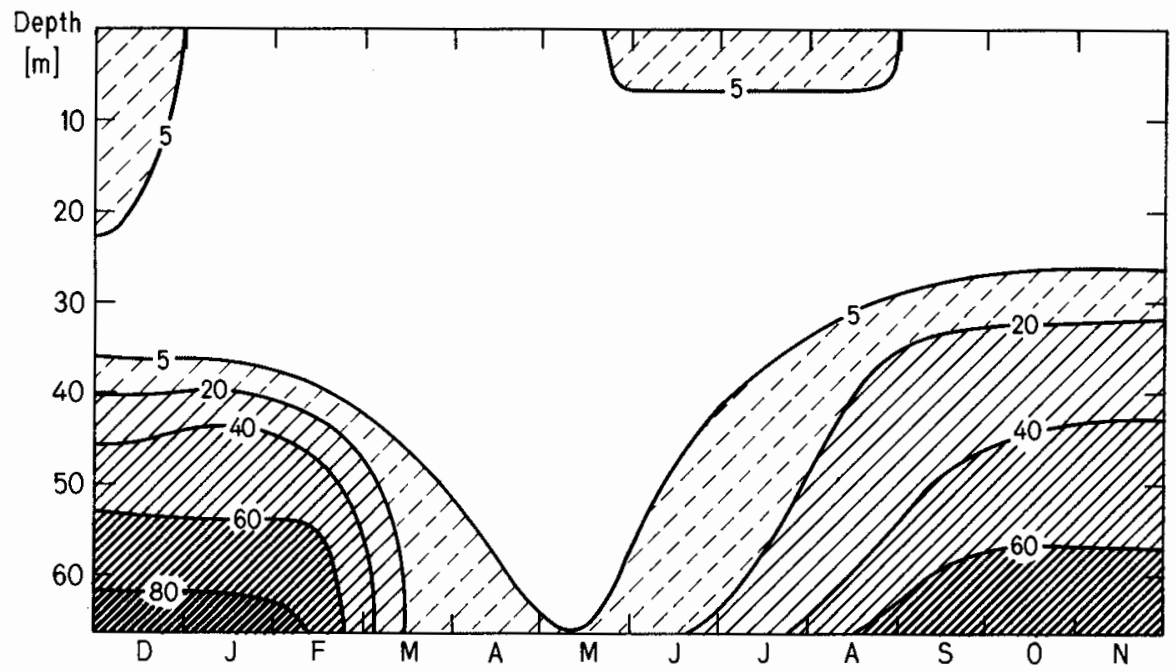

Figure 3. Isopleths of dissolved iron $\left[10^{-8} \mathrm{M}\right]$.

Abb. 3. Isoplethen des gelösten Eisens.

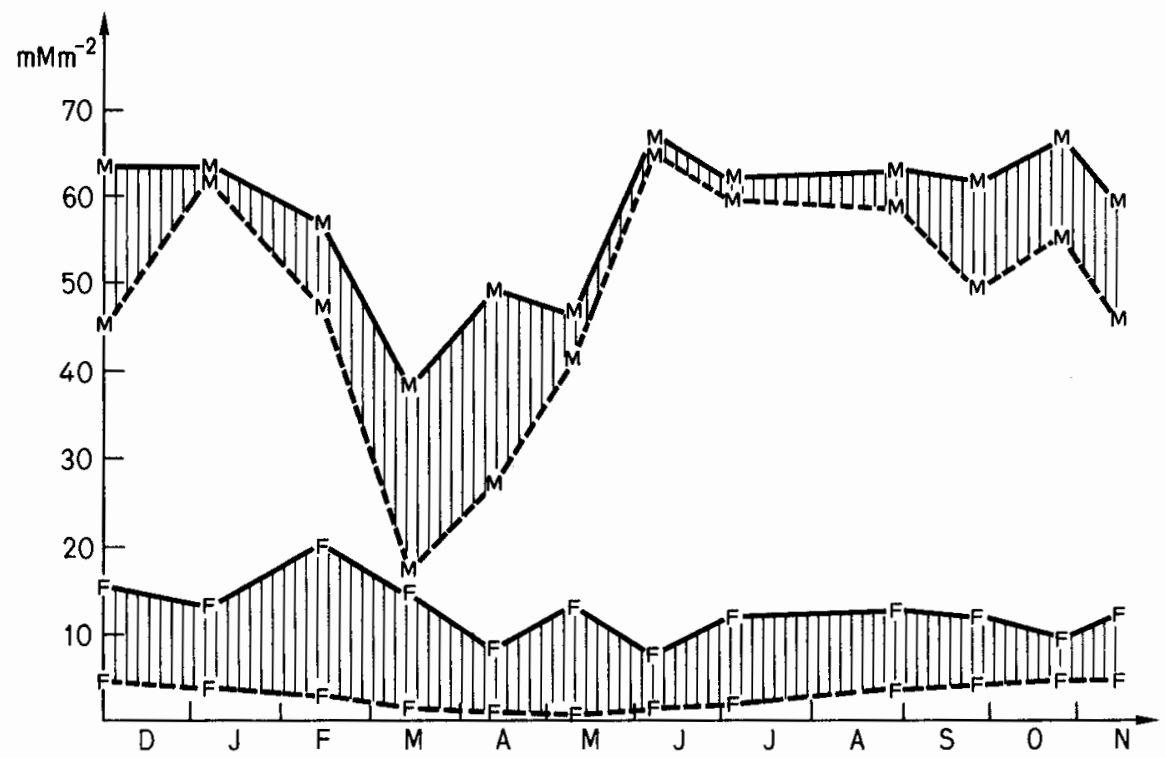

Figure 4. Seasonal variations of manganese (M) and iron (F) quantities [millimole $\mathrm{m}^{-2}$ ] in Lake Baldegg (_- total, --- dissolved, /// particulate).

Abb.4. Saisonale Änderungen der Mangan(M)- und Eisen(F)-Mengen im Baldeggersee (—— total, - - gelöste, /// partikulär). 


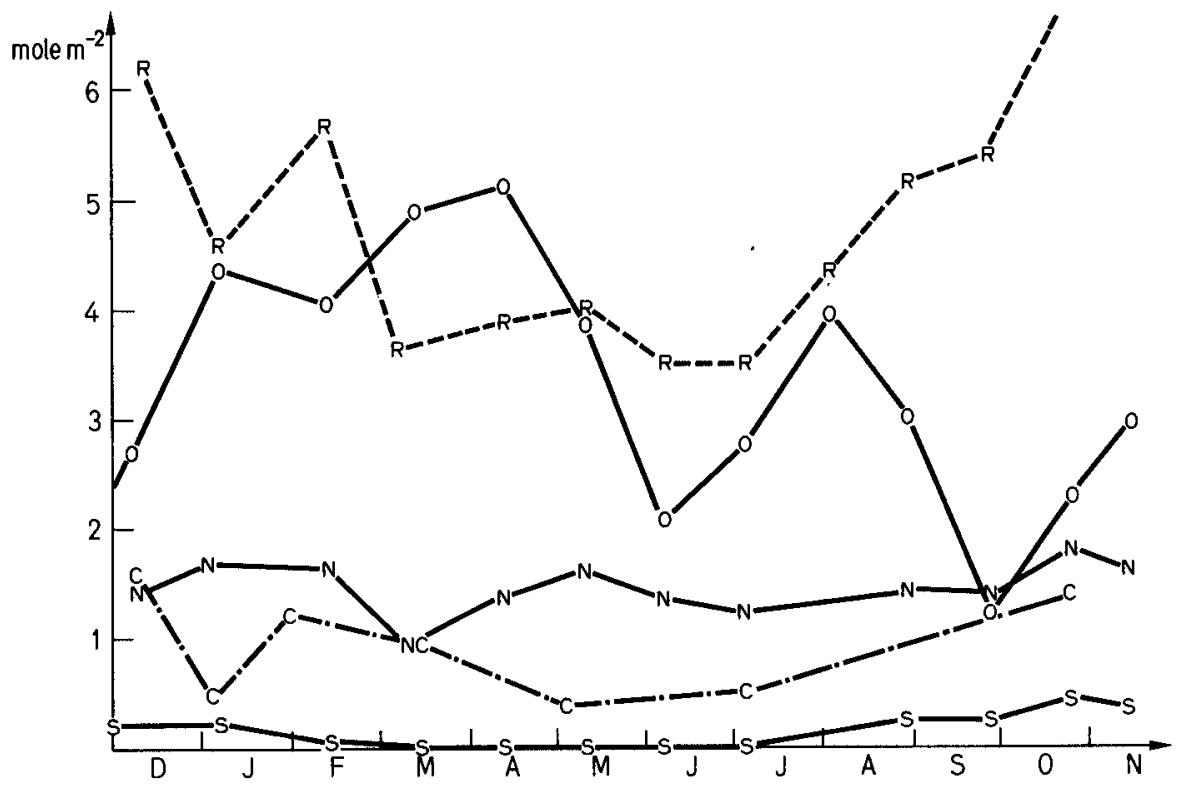

Figure 5. Seasonal variations of oxygen equivalents ( 4 moles of electrons per mole $\mathrm{O}_{2}$ ) in Lake Baldegg [mole $\mathrm{m}^{-2}$ ]. $\mathrm{O}$ : oxygen as $\mathrm{O}_{2}, \mathrm{~N}$ : nitrogen as $\mathrm{NH}_{4}^{+}, \mathrm{C}$ : carbon as $\mathrm{CH}_{4}, \mathrm{~S}$ : sulfur as $\mathrm{HS}^{-}, \mathrm{R}$ : sum of oxygen reducing substances, namely $\mathrm{N}+\mathrm{C}+\mathrm{S}$.

Abb. 5. Saisonale Änderung der Sauerstoffäquivalente (4 Mol Elektronen pro Mol Sauerstoff) im

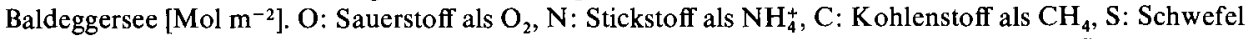
als $\mathrm{HS}^{-}, \mathrm{R}$ : Summe der sauerstoffreduzierenden Substanzen, nämlich $\mathrm{N}+\mathrm{C}+\mathrm{S}$.

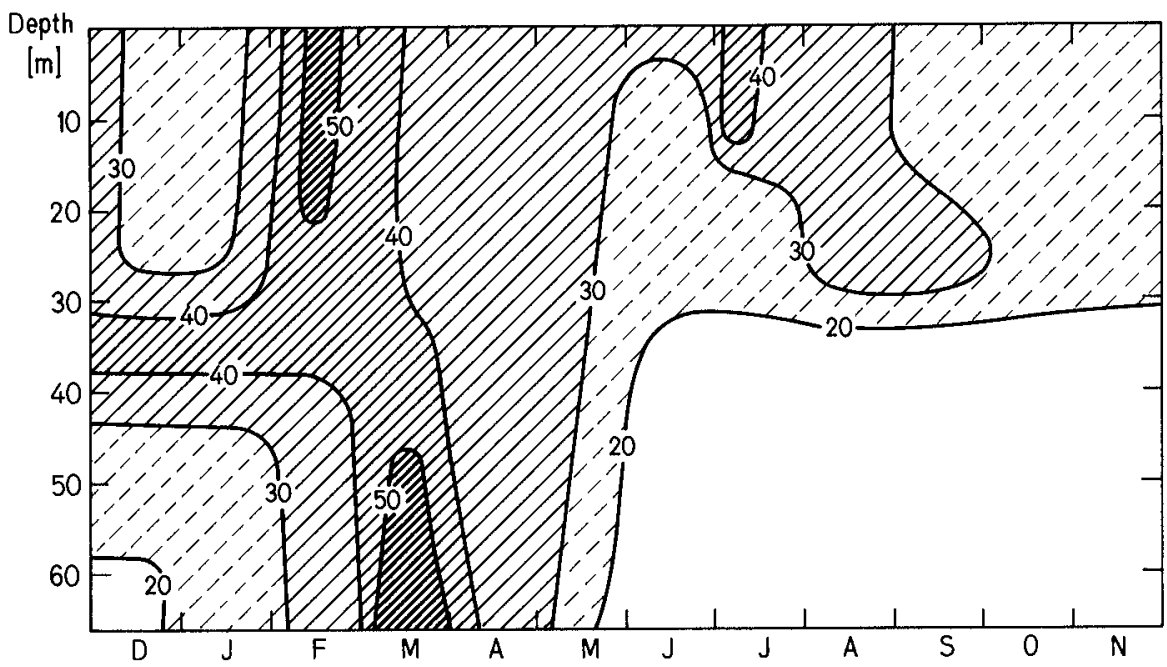

Figure 6. Isopleths of particulate iron $\left[10^{-8} \mathrm{M}\right]$.

Abb. 6. Isoplethen des partikulären Eisens. 
(particulate) and the reduced forms (dissolved) are at approximately $35 \mathrm{~m}$ for iron and $25 \mathrm{~m}$ for manganese. The interfaces of the redox systems $\mathrm{O}_{2} / \mathrm{S}^{2-}$ and $\mathrm{Fe}^{3+} / \mathrm{Fe}^{2+}$ are built up at the same depth, a phenomenon already discussed extensively in other anoxic systems $[8,18]$. Two internal cycles offer two additional transport paths in the downward direction by forming new surfaces for sorption of other species in the upper hypolimnion.

\subsection{Indicators of particulate matter in the water columns}

The isopleths of particulate iron ( $\mathrm{PFe}$ ) show minimum values in the hypolimnion during the second half of the year (fig.6), a period in which the dissolved forms of iron show the highest concentrations (fig. 3). In early spring when the total quantity of dissolved iron in the water column is lowered (fig. 4) the concentration of particulate iron is increased in the hypolimnion and in the epilimnion (fig.6). The latter phenomena is in agreement with the observation [9] that the largest input of allochthonous material to Lake Baldegg is taking place during the end of winter and early spring.

Particulate manganese isopleths show concentration peaks of distinct layers (fig. 7) appearing at depths of $35 \mathrm{~m}$ and $25 \mathrm{~m}$ in spring and late fall.

In these depths Lepothrix sp. known to assimilate iron and/or manganese [10] was identified.

The concentration of particulate nitrogen is a rough measure for the biomass in a water column. The two observed peaks in spring and late summer (fig.8) are in agreement with earlier observations of photosynthetic production (Schiess [11]). It must be noted that the $\mathrm{PN}$-concentrations in the hypolimnion are relatively constant

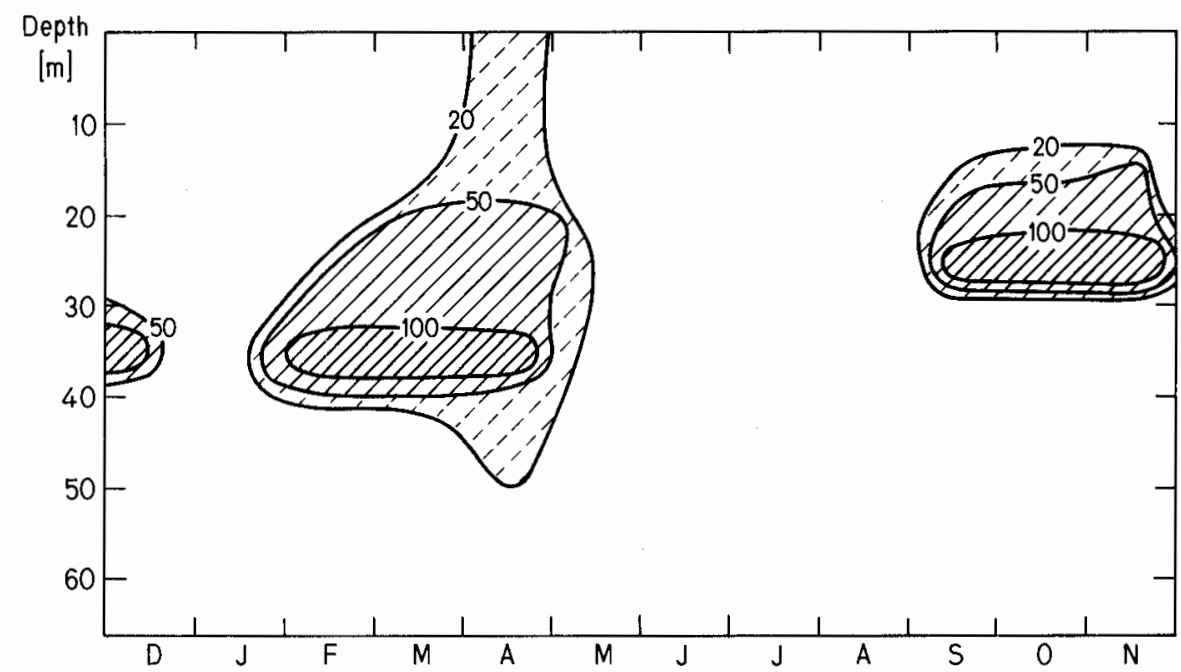

Figure 7. Isopleths of particulate manganese $\left[10^{-8} \mathrm{M}\right]$. Abb. 7. Isoplethen des partikulären Mangans. 
varying between 50 and $90 \mu \mathrm{g} / \mathrm{l}$. With respect to the three parameters $\mathrm{PFe}, \mathrm{PMn}$ and PN, Lake Baldegg is a lake whose allochthonous loading is relatively low in most periods of the year, whose biomass production is high $(\mathrm{PN})$ and whose specific redox properties allow additional precipitation and dissolution processes ( $\mathrm{PFe}$, PMn).
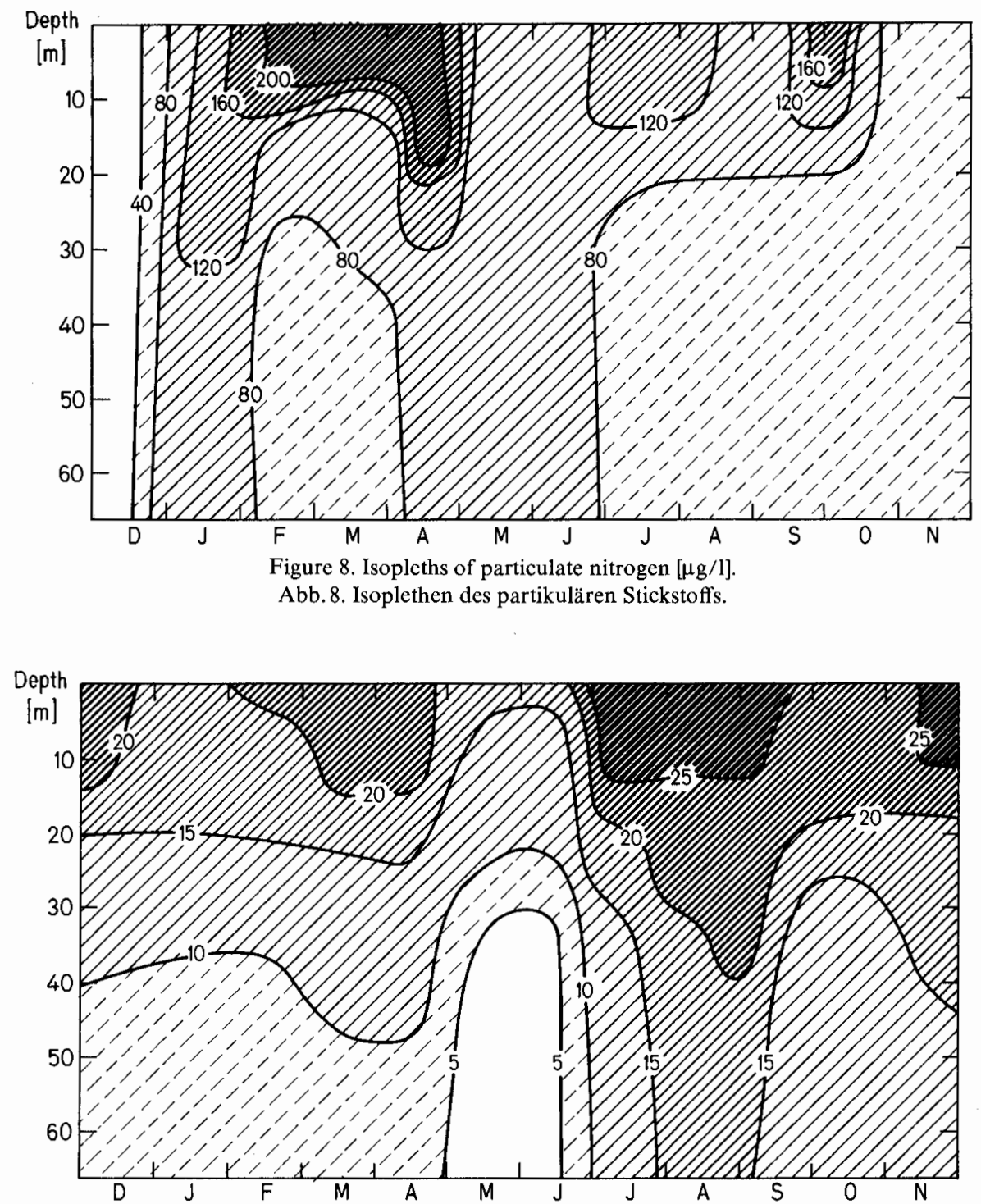

Figure 9. Isopleths of dissolved copper $\left[10^{-9} \mathrm{M}\right]$. Abb. 9. Isoplethen des gelösten Kupfers. 


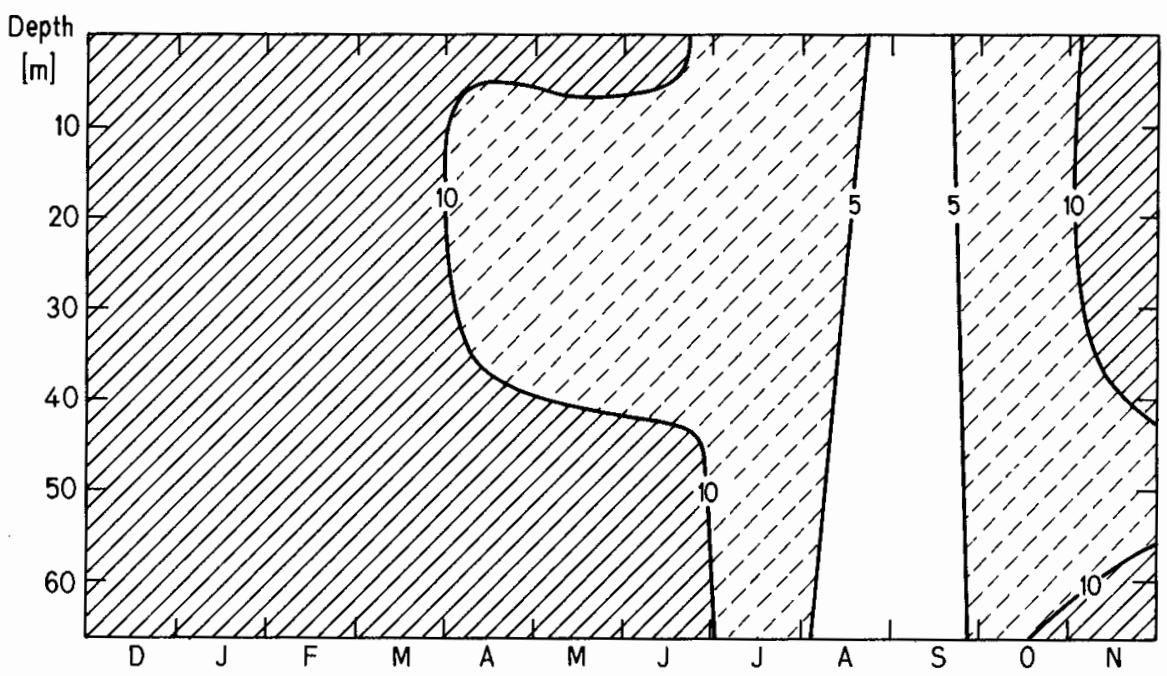

Figure 10. Isopleths of dissolved zinc $\left[10^{-8} \mathrm{M}\right]$.

Abb. 10. Isoplethen des gelösten Zinks.

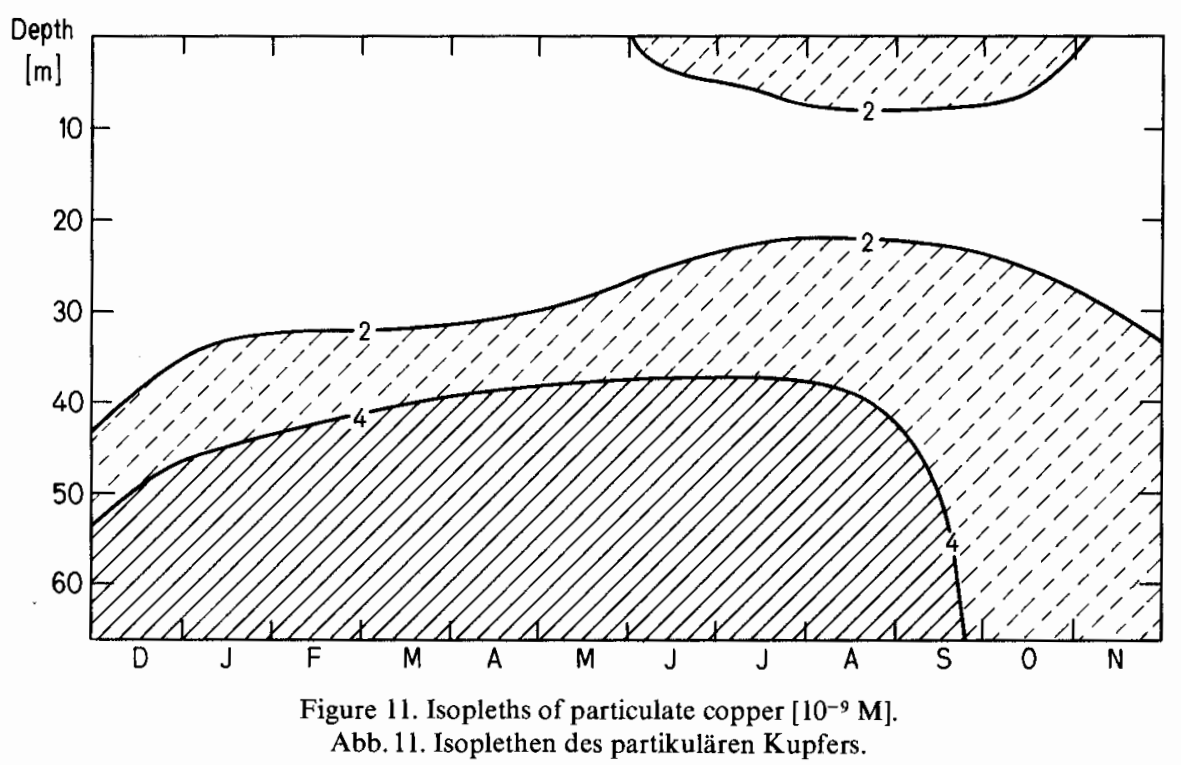

\subsection{Variation of copper and zinc species in the water column}

A comparison of the isopleths of dissolved copper DCu (fig. 9) and dissolved zinc DZn (fig. 10) shows drastic differences. During summer DZn does not show distinct variations with depth and is lowered by a factor 2 in the whole water column. In contrast the concentration of copper in the epilimnion is always higher than in the 


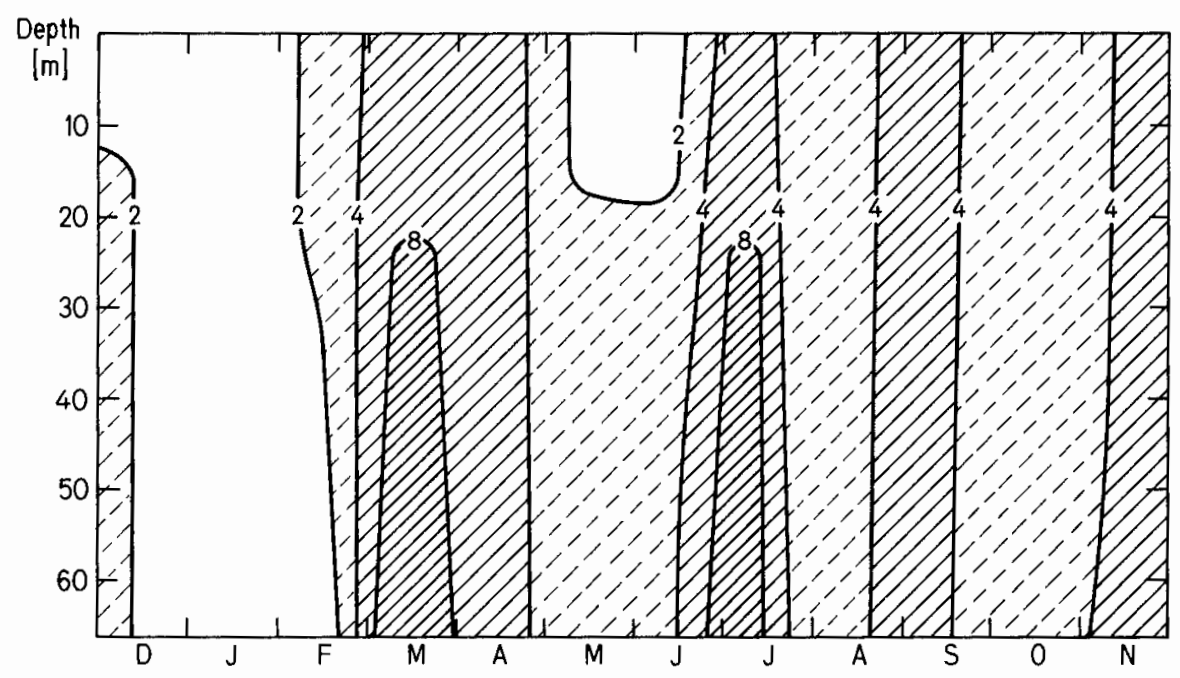

Figure 12. Isopleths of particulate zinc $\left[10^{-8} \mathrm{M}\right.$ ].

Abb. 12. Isoplethen des partikulären Zinks.

hypolimnion by a factor 1.5 to 2 . In addition, the hypolimnion concentration is lowered most strongly in early summer and shortly thereafter increases to maximum values until late summer.

An analogous comparison of the particulate species $\mathrm{PCu}$ (fig. 11) and $\mathrm{PZn}$ (fig. 12) leads to the conclusion that a significant quantity of particulate copper is formed in the hypolimnion, approximately below $35 \mathrm{~m}$. Such a distinct zone of particle formation is not observed for zinc.

For the whole water column the seasonal variation of the contents of total and dissolved zinc and copper is illustrated in figure 13. The particulate portion is greater for zinc than for copper. This must be due to the different assimilation of the two metals by the biomass in the epilimnion (Baccini [3, 4]).

However in the hypolimnion of Lake Baldegg such a distinct difference cannot be observed (compare fig. 9 and 11 with fig. 10 and 12, respectively). The particulate portion of copper is increased. From this phenomenology one may postulate that copper and zinc experience a different distribution among the possible transport paths within the lake.

\subsection{Seasonal variation of the sedimentation rates}

A comparison of the sedimentation rates of copper, iron, zinc, manganese, organic carbon and calcium (fig. 14) shows that the first three elements have similar characteristics, namely two distinct peaks in spring. Organic carbon and calcium reach their highest rates in the summer months. The pronounced maximum of manganese sedimentation in spring is in agreement with the observations already presented in figures 2 and 4. Based on chemical characteristics observed in water columns one may distinguish two periods: 


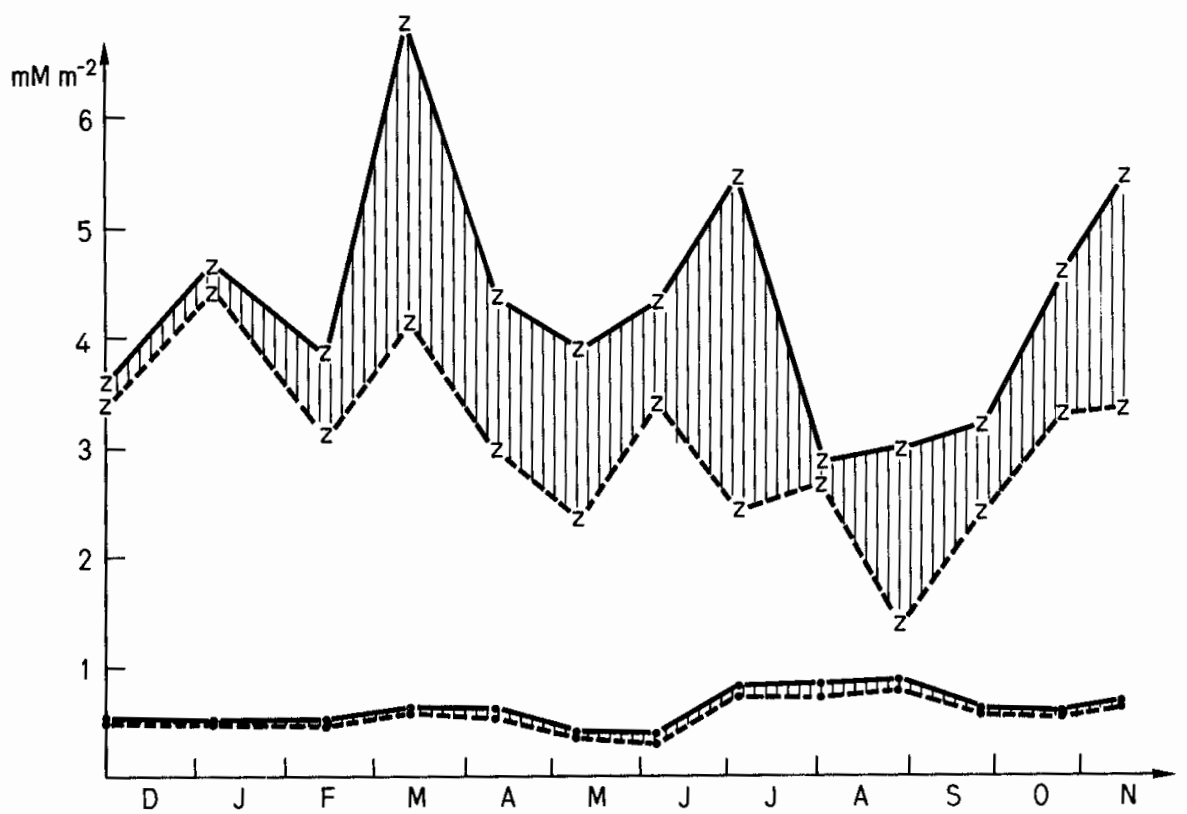

Figure 13. Seasonal variations of zinc $(\mathrm{Z})$ and copper $(\bullet)$ quantities [millimole $\mathrm{m}^{-2}$ ] in Lake Baldegg (_- total, --- dissolved, /// particulate portion).

Abb. 13: Saisonale Änderung der Zink(Z)- und Kupfer(O)-Mengen im Baldeggersee (-— total, --- gelöst, /// partikulär).

Table 2. Matrix of correlation coefficients (multiple regression) of sedimentation rates at the lake bottom. Upper value: period I (from December 1976 to June 1977). Lower value: period II (from June 1977 to November 1977).

Tabelle 2. Matrix der Korrelationskoeffizienten (multiple Regression) von Sedimentationsraten am Seegrund.

\begin{tabular}{|c|c|c|c|c|c|c|c|}
\hline & $\begin{array}{l}\text { Dry } \\
\text { matter }\end{array}$ & $\begin{array}{l}\text { Organic } \\
\text { carbon }\end{array}$ & $\mathrm{Ca}$ & $\mathrm{Mn}$ & $\mathrm{Fe}$ & $\mathrm{Cu}$ & $\mathrm{Zn}$ \\
\hline $\begin{array}{l}\text { Dry } \\
\text { matter }\end{array}$ & 1 & & & & & & \\
\hline $\begin{array}{l}\text { Organic } \\
\text { matter }\end{array}$ & $\begin{array}{l}0.653 \\
0.670\end{array}$ & 1 & & & & & \\
\hline $\mathrm{Ca}$ & $\begin{array}{l}0.523 \\
0.990\end{array}$ & $\begin{array}{r}-0.001 \\
0.562\end{array}$ & 1 & & & & \\
\hline $\mathrm{Mn}$ & $\begin{array}{l}0.595 \\
0.673\end{array}$ & $\begin{array}{l}0.695 \\
0.595\end{array}$ & $\begin{array}{r}-0.166 \\
0.618\end{array}$ & 1 & & & \\
\hline $\mathrm{Fe}$ & $\begin{array}{l}0.597 \\
0.433\end{array}$ & $\begin{array}{l}0.338 \\
0.515\end{array}$ & $\begin{array}{r}-0.203 \\
0.366\end{array}$ & $\begin{array}{l}0.486 \\
0.923\end{array}$ & 1 & & \\
\hline $\mathrm{Cu}$ & $\begin{array}{l}0.403 \\
0.567\end{array}$ & $\begin{array}{l}0.579 \\
0.267\end{array}$ & $\begin{array}{r}-0.564 \\
0.561\end{array}$ & $\begin{array}{l}0.697 \\
0.905\end{array}$ & $\begin{array}{l}0.844 \\
0.886\end{array}$ & 1 & \\
\hline $\mathrm{Zn}$ & $\begin{array}{l}0.727 \\
0.825\end{array}$ & $\begin{array}{l}0.644 \\
0.809\end{array}$ & $\begin{array}{r}-0.189 \\
0.756\end{array}$ & $\begin{array}{l}0.816 \\
0.941\end{array}$ & $\begin{array}{l}0.893 \\
0.815\end{array}$ & $\begin{array}{l}0.907 \\
0.757\end{array}$ & I \\
\hline
\end{tabular}


Period I: Winter/spring from December 1976 to June 1977 with a perturbation of stratification, increased input of allochthonous material and oxygen transport into the hypolimnion.

Period II: Summer/fall from June 1977 to November 1977 with a stabilization of stratification and an increase of electron activity in the hypolimnion.

A correlation analysis (multiple regression) of these rates and the one of dry matter indicate in addition (table 2) that

a) dry matter is strongly correlated to calcium precipitation in period II,

b) zinc is well correlated to the organic carbon, manganese and iron in period II,

c) copper is only well correlated to iron and manganese in period II.

A comparison of these correlation characteristics with those obtained from allochthonous particles (Baccini [3]) indicates a distinct difference. In allochthonous particles a much better correlation between dry matter, organic matter, iron and trace metals was observed than in sedimented matter of Lake Baldegg.

\section{Discussion}

\subsection{Evaluation of the main factors controlling copper and zinc transport}

Copper and zinc can be sedimented on five different types of particles:

1. allochthonous minerals,

2. autochthonous organic substances,

3. calcium carbonate,

4. manganese oxides,

5. iron oxides.

The contribution of each component cannot be determined directly with the present analytical technique. However the seasonal variation of the concentration profiles for particulate copper (fig. 11) indicates that new particles $\mathrm{PCu}$ are formed in the ' $\mathrm{Fe}^{3+} / \mathrm{Fe}^{2+}$ interface' (see chap. 3.1). No correspondence can be observed between the distinct PMn peaks (fig. 7) and the PCu and PZn concentrations (fig. 11, 12).

From chemical experience one would expect that copper is sorbed on newly formed iron(III) hydroxides. Apart from this two other reasons could be taken into account:

1. The sulfide anion appearing in an anaerobic hypolimnion could form an unsoluble copper salt. A comparison of figures 1 and 11 shows clearly that such a process cannot be of importance. In periods of non detectable sulfide concentrations $\mathrm{PCu}$ is also formed.

2. Copper experiences a change in speciation at a depth between 20 and $30 \mathrm{~m}$ and is sorbed at particles entering the hypolimnion.

From previous investigations we know that the dissolved copper is complexed with organic ligands [12]. Although we do not have any detailed information about the chemical composition of organic ligands, the parameter DOC could indicate their possible variation in concentration. According to figure 15 no significant differences between epilimnion and hypolimnion can be observed. Furthermore the hypolimnic 
water shows the same copper binding capacity per $\mathrm{mg} \mathrm{DOC}$ as the epilimnic one (Baccini [13]).

There are no indications from sedimentation rates (fig. 14) and from concentration profiles (fig. 11, 12) that biogenic calcium carbonate is a scavenger for copper and

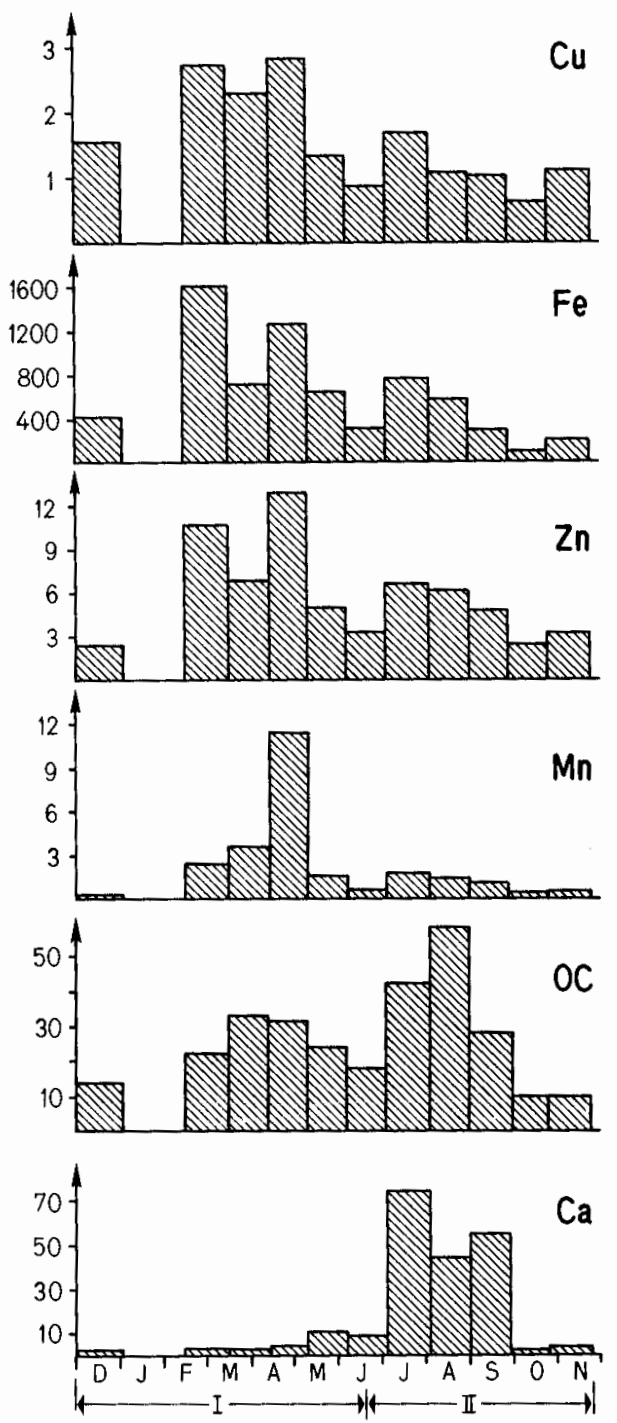

Figure 14. Seasonal variation of sedimentation rates, found in sedimentation traps $0.5 \mathrm{~m}$ above lake bottom. $\mathrm{Cu}, \mathrm{Fe}, \mathrm{Zn}, \mathrm{Mn}$ [micromole $\mathrm{m}^{-2} \mathrm{~d}^{-1}$ ], OC (organic carbon) $\left[\mathrm{g} \mathrm{m}^{-2} \mathrm{~d}^{-1}\right.$ ], Ca [millimole $\mathrm{m}^{-2} \mathrm{~d}^{-1}$ ]. Abb. 14. Saisonaler Verlauf der Sedimentationsraten, ermittelt in Sedimentpfannen $0,5 \mathrm{~m}$ oberhalb des Seegrundes. $\mathrm{Cu}, \mathrm{Fe}, \mathrm{Zn}, \mathrm{Mn}$ [Mikromol $\mathrm{m}^{-2} \mathrm{~d}^{-1}$ ], OC (organischer Kohlenstofm) [g $\mathrm{m}^{-2} \mathrm{~d}^{-1}$ ], Ca [Millimol $\left.\mathrm{m}^{-2} \mathrm{~d}^{-1}\right]$. 
zinc. The particulate organic matter however is most likely responsible for the pronounced sedimentation (table 2) between June and August and the resulting decrease of $\mathrm{Zn}$ in the lake (fig. 13). In the same period copper shows a strong increase in the dissolved concentration of the hypolimnion. This cannot be the result of a redissolution process from the sediment since the concentration profile does not resemble those of manganese, iron and sulfide (fig. 1-3). This phenomenon must be due to an accelerated sedimentation and subsequent dissolution of phytoplankton which experience a strong allochthonous loading (fig.9) of copper.

In conclusion one may postulate the following transport processes for copper and zinc:

a) Both elements are sedimented partly on allochthonous particles to the sediment.

b) Dissolved zinc and copper are sorbed by the biomass in the epilimnion. The former element is sorbed more strongly than the latter. A portion of the organic particles is mineralized leading to a redissolution of copper and zinc in the hypolimnion.

c) In addition copper is sorbed on newly formed iron particles in the upper hypolimnion and is sedimented.

This hypothesis has to be examined by an experimental and a theoretical method. The experimental method should give a qualitative answer to the question: Can freshly precipitated iron in hypolimnic water of Lake Baldegg adsorb copper but not zinc?

In a theoretical approach an empirical transport model for the hypolimnion should test the quantitative aspects of the proposed transport mechanisms.

\subsection{Experimental evidences for a selective precipitation of copper in the hypolimnion}

In order to evaluate the influence of the possible scavengers such as calcium carbonate, manganese oxides and iron(III) oxides on copper and zinc transport, samples were taken in $300 \mathrm{ml}$ infusion bottles [7] to perform the following laboratory experiments:

a) $\mathrm{CaCO}_{3}$

- Epilimnion, depth $2 \mathrm{~m}, \mathrm{pH}=8.7, T=18^{\circ} \mathrm{C}$.

- The calcium carbonate precipitation was induced by increasing $p H$ to 9.4 with $0.1 \mathrm{~N} \mathrm{NaOH}$ and equilibrating during 24 hours.

b) Mn-oxides

- 'Mn+1V $/ \mathrm{Mn}^{+1 \mathrm{II}}$ interface', depth $20-30 \mathrm{~m}$ (fig. 2), $\mathrm{T}=5^{\circ} \mathrm{C}$.

-- The manganese precipitation was induced by adding $1 \mathrm{ml}$ air and equilibrating during 24 hours.

c) Fe-oxides

- ' $\mathrm{Fe}^{\mathrm{III}} / \mathrm{Fe}^{\mathrm{II}}$ interface', depth $35-65 \mathrm{~m}$ (fig. 3 ), $\mathrm{T}=5-4^{\circ} \mathrm{C}$.

- The iron precipitation was induced by adding $1 \mathrm{ml}$ air and equilibrating during 24 hours. 
Copper and zinc concentrations were increased separately to $10^{-7}$ and $10^{-6} \mathrm{M}$ resp. before adding $\mathrm{NaOH}$ or air.

In experiment $\mathrm{c}$ the manganese oxides were not coprecipitated, i.e. the experimental set-up allowed to oxydize the iron(II) selectively. Samples without addition of $\mathrm{OH}^{-}$ ions or air served as controls. The results are summarized in figure 16.

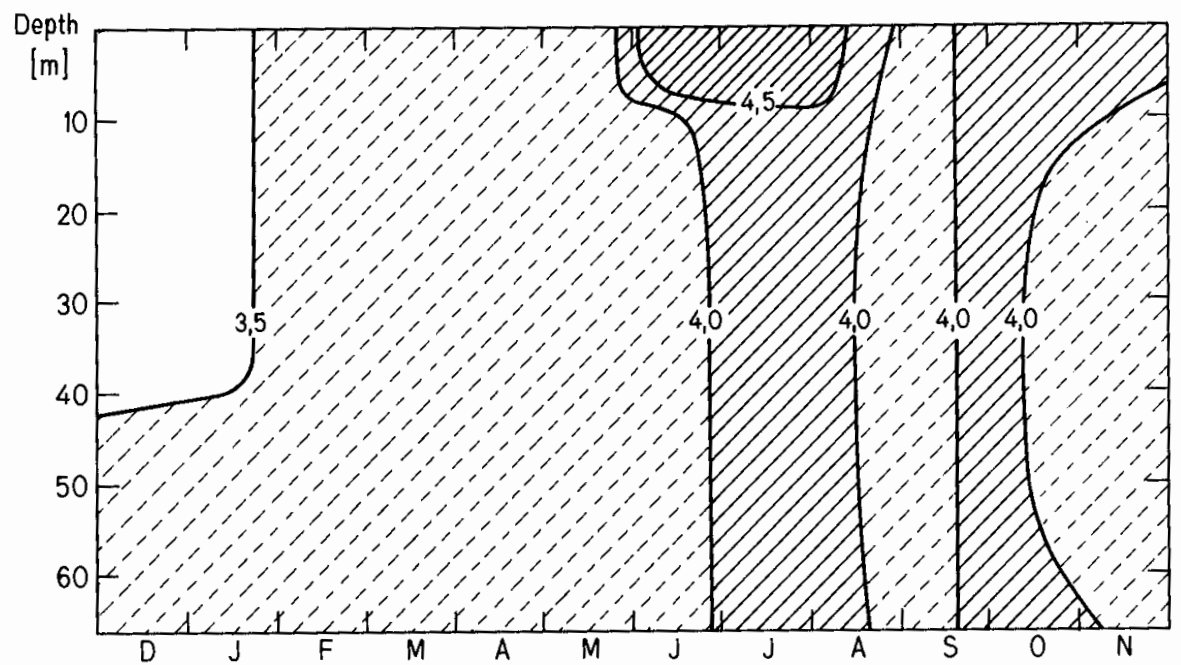

Figure 15. Isopleths of dissolved organic carbon $\left[\mathrm{mg} \mathrm{l}^{-1}\right]$.

Abb. 15. Isoplethen des gelösten organischen Kohlenstoffs.

Ca-precipitation

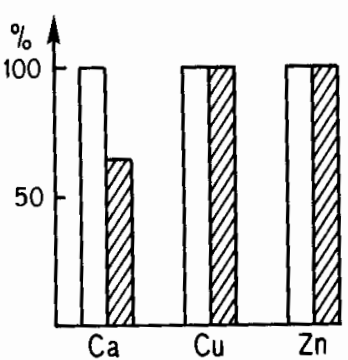

Mn-precipitation

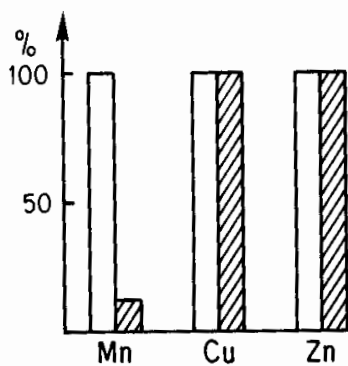

Fe-precipitation

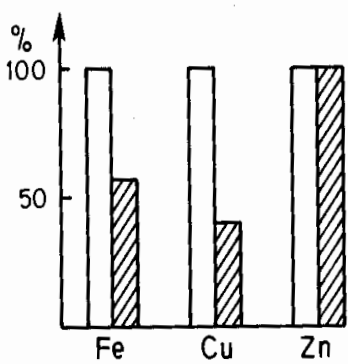

Figure 16. Coprecipitation of copper and zinc in laboratory experiments with hypolimnic samples of

Lake Baldegg. Initial concentrations $(100 \%)$. Ca: $3.3 \times 10^{-3} \mathrm{M}, \mathrm{Fe}: 5.1 \times 10^{-7} \mathrm{M}, \mathrm{Mn}: 1.3 \times 10^{-6} \mathrm{M}, \mathrm{Cu}$ :

$1.0 \times 10^{-7} \mathrm{M}, \mathrm{Zn}: 1.0 \times 10^{-6} \mathrm{M} . \mathrm{D}$ : control (100\%). 国: perturbed system (adding $\mathrm{OH}^{-}$for $\mathrm{Ca}$ precipitation or air for $\mathrm{Mn}$ - or Fe-precipitation) indicating the percentage of metal in the dissolved phase.

Abb. 16. In Laborexperimenten beobachtete Fällungen von Kupfer und Zink in hypolimnischen Proben des Baldeggersees. Ausgangskonzentrationen (100\%). $\square$ : Kontroile (100\%). 四: Gestörtes System (Zugabe von $\mathrm{OH}^{-}$-Ionen für die Ca-Fällung oder von Luft für die Mn- oder Fe-Fällung). Angabe des prozentualen Anteils der Ausgangskonzentration, der in der gelösten Phase gefunden wird. 
Copper is only coprecipitated with iron, whereas zinc is not influenced by any of the three.

These findings in laboratory experiments do not exclude any other but much slower precipitation reactions with the same elements. From a qualitative point of view however they are in good agreement with earlier results [4] and the conclusions drawn in chapter 4.1 , namely that calcium carbonate does not significantly influence copper and zinc transport and that zinc and copper differ clearly in their behaviour in the hypolimnion.

\subsection{An empirical model of copper fluxes in the anaerobic hypolimnion}

On the basis of the phenomenology discussed in chapter 4.1 and the experimental support presented in chapter 4.2 a hypolimnic flux scheme for iron and copper is proposed (fig. 17). This empirical model should help to discuss three main questions:

1. What is the importance of the additional hypolimnic transport path starting at the ' $\mathrm{Fe}^{3+} / \mathrm{Fe}^{2+}$ interface' from a qualitative point of view?

2. Can the estimated ratio of $\mathrm{Cu}: \mathrm{Fe}$ in the newly formed particles give informations about their chemical nature?

3. Is the proposed flux scheme able to predict the observed copper concentration variations in the hypolimnion?

In order to estimate the individual fluxes the following assumptions are made:

\section{Particulate allochthonous metal $\left(P M_{A}\right)$}

The flux of allochthonous particulate iron is calculated as follows:

$$
\mathrm{PFe}_{\mathrm{A}}=\left[\mathrm{PFe}_{\mathrm{Ep}}\right] \cdot \mathrm{v}_{\mathrm{A}},
$$

Anaerobic Hypolimnion

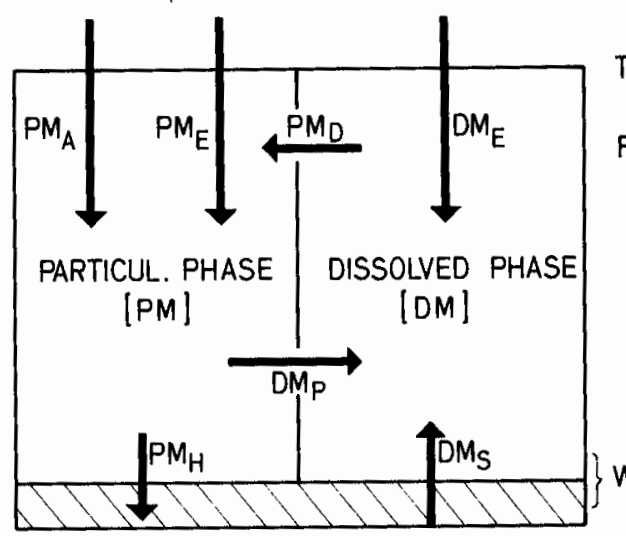

Thermocline $\mathrm{Fe}^{3+} / \mathrm{Fe}^{2+}$ interface Water / Sediment interface

Figure 17. Flux scheme for iron and copper (M) in the hypolimnion of Lake Baldegg (see list of symbols).

Abb. 17. Flußschema für Eisen und Kupfer (M) im Hypolimnion des Baldeggersees (konsultiere die List of symbols). 
where $\left[\overline{\mathrm{PFe}} \overline{\mathrm{Ep}_{\mathrm{p}}}\right]$ is the mean concentration of particulate iron in the epilimnion. $\mathrm{v}_{\mathrm{A}}$ is the mean sedimentation rate $\left(\mathrm{m} \mathrm{d}^{-1}\right)$ calculated from data given in figure 14 . It is assumed that the autochthonous biogenic contribution to $\mathrm{PF}_{\mathrm{Epi}}$ can be neglected (Baccini [3]).

The corresponding copper flux is given by

$$
\mathrm{PCu}_{\mathrm{A}}=\mathrm{f} \mathrm{PFe}_{\mathrm{A}},
$$

i.e. it is assumed that the allochthonous particle has a constant $\mathrm{Fe}: \mathrm{Cu}$ ratio. $\mathrm{f}$ is given by the ratio found in particles of the affluent $\operatorname{RON}\left(\mathrm{f}=1.7 \times 10^{-3}\right)$.

\section{Particulate autochthonous metal $\left(P M_{E}\right)$}

For this flux the sedimenting organic material of the epilimnic primary production is considered. The contribution to the hypolimnic PFe-reservoir can be neglected [3]. The copper flux is given by

$$
\mathrm{PCu}_{\mathrm{E}}=\mathrm{nPN}_{\mathrm{E}} \text {. }
$$

It is assumed that the organic particle has a constant $\mathrm{N}: \mathrm{Cu}$ ratio. $\mathrm{n}$ is given by the ratio found in the plankton of Lake Baldegg (n: $\left.1.3 \times 10^{-4},[4]\right)$.

The flux of particulate nitrogen $\mathrm{PN}_{\mathrm{E}}$ entering the hypolimnion is given by

$$
\mathrm{PN}_{\mathrm{E}}=[\overline{\mathrm{PN}} \overline{\mathrm{Epi}}] \cdot \mathrm{v}_{\mathrm{E}}
$$

where $[\overline{\mathrm{PN}} \overline{\mathrm{Ep}}]$ is the mean concentration of particulate nitrogen in the epilimnion and $\mathrm{V}_{\mathrm{E}}$ is the mean sedimentation rate for phytoplankton found in limno-corrals [4] and an eutrophic lake [14].

\section{Dissolved epilimnic metal $D M_{E}$}

The flux of dissolved iron from the epilimnion is very small and can be neglected. The flux of copper is described with a vertical Eddy diffusion

$$
\mathrm{DCu}_{\mathrm{E}}=-\mathrm{k}_{\mathrm{TC}}(\mathrm{Z}) \stackrel{\frac{\partial[\mathrm{Cu}]}{\partial \mathrm{Z}}}{\left.\right|_{\mathrm{TC}}},
$$

where $\mathrm{k}_{\mathrm{TC}}(\mathrm{Z})$ is the Eddy diffusion coefficient determined from temperature profiles near the thermocline [15]. The concentration gradient is given from data presented in figure 9.

\section{Dissolved metal from the sediment $D M_{S}$}

The iron flux $\mathrm{DFe}_{\mathrm{S}}$ can be estimated with the assumption of a vertical Eddy diffusion with data from figure 3 and temperature profiles [1]

$$
\mathrm{DFe}_{\mathrm{S}}=\left.\mathrm{k}_{\mathrm{S}}(\mathrm{Z}) \frac{\partial[\mathrm{Fe}]}{\partial \mathrm{Z}}\right|_{\mathrm{Z} \approx \mathrm{TC}}
$$




\section{Particulate metal fux to the sediment $P M_{H}$}

It is assumed that the allochthonous material entering the hypolimnion passes through it without any significant chemical and physical transformation [3]. At the ' $\mathrm{Fe}^{3+} / \mathrm{Fe}^{2+}$ interface' new particulate iron is constantly formed by oxidation resulting in a flux $\mathrm{PFe}_{\mathrm{D}}$. In a steady state for the DFe-reservoir this flux $\mathrm{PFe}_{\mathrm{D}}$ must be equal to $\mathrm{DFe}_{\mathrm{S}}$ [eq. (6)].

The corresponding copper flux $\mathrm{PCu}_{\mathrm{D}}$ must be coupled with $\mathrm{PFe}_{\mathrm{D}}$ based on the conclusion drawn in chapter 4.2:

$$
\mathrm{PCu}_{\mathrm{D}}=\mathrm{c} \cdot \mathrm{PFe}_{\mathrm{D}} .
$$

The resulting fluxes into the sediment are

$$
\begin{aligned}
& \mathrm{PFe}_{\mathrm{H}}=\mathrm{PFe}_{\mathrm{A}}+\mathrm{PFe}_{\mathrm{D}}, \\
& \mathrm{PCu}_{\mathrm{H}}=\mathrm{PCu}_{\mathrm{A}}+\mathrm{PCu}_{\mathrm{E}}+\mathrm{PCu}_{\mathrm{D}} .
\end{aligned}
$$

The fluxes $\mathbf{P M}_{\mathrm{H}}$ have been measured (fig. 14). The flux $\mathbf{P C u _ { \mathrm { E } } ^ { \prime }}$ is smaller than $\mathrm{PCu}_{\mathrm{F}}$ considering a decomposition process of the organic material within the hypolimnion:

$$
\mathrm{PCu}_{\mathrm{E}}^{\prime}=\mathrm{d} \cdot \mathrm{PCu}_{\mathrm{E}} .
$$

It follows further that the flux from $\mathrm{PCu}$ to $\mathrm{DCu}$ due to this decomposition is

$$
\mathrm{DCu}_{\mathrm{p}}=(1-\mathrm{d}) \mathrm{PCu}_{\mathrm{E}} .
$$

In a steady state for the DFe-reservoir the proposed hypolimnic Fe cycle would also induce a copper cycle if one assumes a remobilization process within the water/ sediment interface, namely

$$
\mathrm{DCu}_{\mathrm{S}}=\mathrm{c} \cdot \mathrm{DFe}_{\mathrm{S}} .
$$

With the given set of equations (1)-(12) for the proposed flux scheme the first two main questions posed at the beginning can be answered as follows:

1. Relative importance of additional hypolimnic fluxes

$$
\begin{aligned}
& \frac{\mathrm{PFe}_{\mathrm{D}}}{\mathrm{PFe}_{\mathrm{H}}}=\frac{\mathrm{k}_{\mathrm{TC}}(\mathrm{Z}) \frac{\partial[\mathrm{Fe}]}{\partial \mathrm{Z}}}{\mathrm{PFe}_{\mathrm{H}}}, \\
& \frac{\mathrm{PCu}_{\mathrm{D}}}{\mathrm{PCu}_{\mathrm{H}}}=\frac{\mathrm{c} \cdot \mathrm{PFe}_{\mathrm{D}}}{\mathrm{fPFe} \mathrm{A}_{\mathrm{A}}+\mathrm{dn} \mathrm{PN}_{\mathrm{E}}+\mathrm{CPFe}}=\frac{\mathrm{PCu}_{\mathrm{H}}-\mathrm{fFe}_{\mathrm{A}}-\mathrm{dn} \mathrm{PN}_{\mathrm{E}}}{\mathrm{PCu}_{\mathrm{H}}}
\end{aligned}
$$


The time period of October 1977 was chosen to calculate the relative fluxes. At this time the DFe-reservoir is in a steady state and the $\mathrm{Fe}^{2+}$-concentration gradient is at a maximum (fig. 3). At the same time the overall sedimentation rate of iron namely $\mathrm{PFe}_{\mathrm{H}}$ is at a minimum (fig. 14). The estimated flux ratios could therefore be the highest ones.

2. The $\mathrm{Fe}: \mathrm{Cu}$ ratio $\mathrm{c}$ in the newly formed particles is given by equations (7), (13) and (14).

The values for the chosen parameters in the results are presented in table 3.

According to the hypothesis the two fluxes $\mathrm{PFe}_{\mathrm{D}}$ and $\mathrm{PCu}_{\mathrm{D}}$ should give the same sedimentation rates, namely

$$
\mathrm{v}_{\mathrm{H}}=\frac{\mathrm{PFe}_{\mathrm{D}}}{\left[\overline{\mathrm{PFe}_{\mathrm{D}}}\right]} \approx \frac{\mathrm{PCu}_{\mathrm{D}}}{\left[\overline{\mathrm{PCu_{ \textrm {D } }}}\right]} .
$$

While the additional iron flux is of minor importance (approx. 3\%) the corresponding copper flux can amount up to $50 \%$ of the total. The similar values of the sedimentation rates (calculated from independent variables) support the hypothesis of a common particle: The estimated $\mathrm{Cu}: \mathrm{Fe}$ ratio is relatively low and in the same order of magnitude as the ratio DCu:DFe found in the hypolimnion from a chemical point of view two mechanisms for the particle forming process can be postulated:

1. Iron(III) hydroxides are formed. If this process is mainly an inorganic one the particle size can vary strongly [16]. The separation technique chosen $(0.45 \mu \mathrm{m}$ filter $)$ can only detect particles having diameters approx. $\geqslant 4,500 \AA$. Even if the surface adsorption of such particles would be strongly specific for copper they would not

Table 3. Estimated additional fluxes of particulate iron and copper in the hypolimnion (October 1977).

Tabelle 3. Abschätzung der zusätzlichen partikulären Eisen- und Kupferflüsse im Hypolimnion (Oktober 1977).

\begin{tabular}{llr}
\hline & Flux mole $\mathrm{m}^{-2} \mathrm{~d}^{-1 *}$ & $\begin{array}{r}\text { Percentage of total } \\
\text { sedimentation }\end{array}$ \\
\hline Iron & $3 \times 10^{-6}$ & 3 \\
Copper & $3 \times 10^{-7}$ & 52 \\
\hline
\end{tabular}

$\mathrm{Cu}:$ Fe ratio $\mathrm{c}$ in the newly formed particle: $1: 10$

Comparison of sedimentation rates [eq. (15)]:

$\mathrm{v}_{\mathrm{H}}(\mathrm{Cu}): 0.1 \mathrm{md}^{-1}$

$\mathrm{v}_{\mathrm{H}}(\mathrm{Fe}): 0.4 \mathrm{~m} \mathrm{~d}^{-1}$

* Parameter chosen:

$\mathrm{k}_{\mathrm{Z}(\mathrm{TC})}=10^{-2} \mathrm{~cm}^{2} \mathrm{sec}^{-1}[15]$

$\mathrm{v}_{\mathrm{A}}=2.0 \mathrm{md}^{-1}[14]$

$\mathrm{v}_{\mathrm{E}}=0.2 \mathrm{md}^{-1}[4,14]$

$\mathrm{d}=0.5$ (estimation)

$\frac{\partial[\mathrm{Fe}]}{\partial \mathrm{Z}} \mid=2 \times 10^{-5} \mathrm{molem}^{-4}$ 
attain a $\mathrm{Fe}: \mathrm{Cu}$ ratio of approx. 10:1. Smaller particles of the same type could be adsorbed on larger particles (e.g. clays). This would mean however that such particles have surfaces that adsorb not specifically copper, a conclusion that is in agreement with chemical experience [16]. Again a ratio of 10:1 could hardly be achieved.

2. The iron(II) diffusing from the sediment to the ' $\mathrm{Fe}^{3+} / \mathrm{Fe}^{2+}$ interface' is complexed with organic molecules. Experimental evidences for such a chemical speciation have been stated [17]. Copper is also bound in organic complexes [12]. It is reasonable to assume that in such a molecule with many binding sites the ratio $\mathrm{Fe}: \mathrm{Cu}$ resembles the one found in the dissolved phase in the hypolimnion. The oxidation of the iron(II) in the complex could lead to the formation of hydroxoorgano complexes of $\mathrm{Fe}$ (III) being able to form hydroxide bridges. The result could be a flocculation process of organic molecules maintaining the $\mathrm{Fe}: \mathrm{Cu}$ ratio. Zinc which is not complexed with organic ligands [4] in the dissolved phase is excluded from this transport process.

However the existence of stable Fe(II) complexes with natural organic ligands is not proven. Davison [19] showed with polarographic measurements that $\mathrm{Fe}(\mathrm{II})$ in concentration ranges between $10^{-6}$ and $10^{-4} \mathrm{M}$ is in the aquated form. In Lake Baldegg the dissolved iron concentration was always below $10^{-6} \mathrm{M}$ (fig. 3) and could not be characterized analogously.

The third question can be discussed in a hypolimnic model system consisting of one dissolved and two particulate phases. The latter two consider the two different chemical forms, namely copper in particulate organic matter $\mathrm{PCu}_{\mathrm{o}}$ and copper in particulate iron $\mathrm{PCu}_{\mathrm{Fe}}$, stemming from the 'iron wheel'.

A one-dimensional diffusion model with boxes of $2.5 \mathrm{~m}$ depth is used considering the orographic properties of Lake Baldegg. Observed concentration gradients in the water column due to fluxes from the sediment (e.g. methane) can be simulated with this model [15]. For the hypolimnion of Lake Baldegg the lateral mixing process from the side walls of each box is the decisive factor for the distribution of the redissolving substances [15].

In the period from June to August 1977 there is a strong increase of dissolved copper in the hypolimnion (fig.9) whereas the particulate copper concentration remains practically constant (fig. 11).

The following set of differential equations are used to describe the observed phenomena:

$$
\begin{aligned}
& \frac{\partial[\mathrm{DCu}]}{\partial \mathrm{t}}=\frac{1}{\mathrm{~A}_{\mathrm{Z}}}\left|\frac{\partial \mathrm{A}}{\partial \mathrm{Z}}\right| \mathrm{DCu_{ \textrm {S } }}+\frac{1}{\mathrm{~A}_{\mathrm{Z}}} \frac{\partial}{\partial \mathrm{Z}}\left[\mathrm{A}_{\mathrm{Z}} \mathrm{k}(\mathrm{Z}) \frac{\partial[\mathrm{DCu}]}{\partial \mathrm{Z}}\right]+\mathrm{J}_{\mathrm{D}}, \\
& \frac{\partial\left[\mathrm{PCu}_{\mathrm{O}}\right]}{\partial \mathrm{t}}=\frac{1}{\mathrm{~A}_{\mathrm{Z}}} \frac{\partial}{\partial \mathrm{Z}}\left[\mathrm{A}_{\mathrm{Z}} \mathrm{k}(\mathrm{Z}) \frac{\partial\left[\mathrm{PCu}_{\mathrm{O}}\right]}{\partial \mathrm{Z}}\right]-\mathrm{v}_{\mathrm{E}} \frac{\partial\left[\mathrm{PCu}_{\mathrm{O}}\right]}{\partial \mathrm{Z}}+\mathrm{J}_{\mathrm{P}_{\mathrm{O}}}, \\
& \frac{\partial\left[\mathrm{PCu}_{\mathrm{Fe}}\right]}{\partial \mathrm{t}}=\frac{1}{\mathrm{~A}_{\mathrm{Z}}} \frac{\partial}{\partial \mathrm{Z}}\left[\mathrm{A}_{\mathrm{Z}} \mathrm{k}(\mathrm{Z}) \frac{\partial\left[\mathrm{PCu}_{\mathrm{Fe}}\right]}{\partial \mathrm{Z}}\right]-\mathrm{v}_{\mathrm{H}} \frac{\partial\left[\mathrm{PCu}_{\mathrm{Fe}}\right]}{\partial \mathbf{Z}}+\mathbf{J}_{\mathrm{PFe}_{\mathrm{Fe}},}
\end{aligned}
$$


where

$\mathrm{Z}=\operatorname{depth}(\mathrm{m})$

$A_{Z}=$ lake surface at depth $Z$,

$\mathrm{k}(\mathrm{Z})=$ Eddy diffusion coefficient at depth $\mathrm{Z}\left(\mathrm{m}^{-2} \mathrm{~d}^{-1}\right)$,

$\mathrm{J}_{\mathrm{D}}, \mathrm{J}_{\mathrm{PO}}, \mathrm{J}_{\mathrm{PFe}_{\mathrm{Fe}}}=$ source and sink function of chemical reactions (mole $\mathrm{m}^{-3} \mathrm{~d}^{-1}$ ).

The chemical reactions are taken as first order reactions. The transfer from DCu to $\mathrm{PCu}_{\mathrm{Fe}}$ is given by

$$
\mathrm{P}_{\mathrm{PFe}_{\mathrm{Fe}}}=\mathrm{K}_{1} \quad[\mathrm{DCu}] \text {, }
$$

where $K_{1}$ can be estimated from the equations describing the 'iron wheel' (table 2) giving a range between 0.016 and 0.004 .
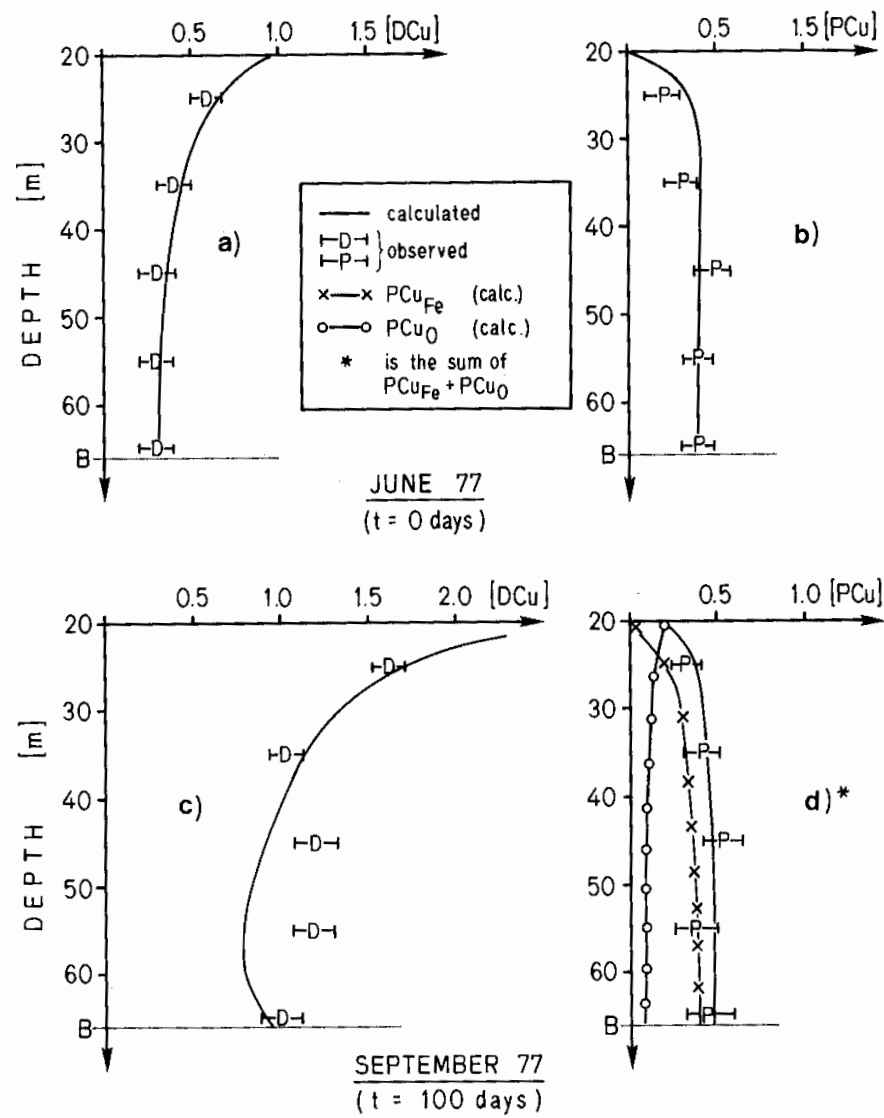

Figure 18. Comparison of simulated and observed copper concentrations in the hypolimnion $\left[10^{-8} \mathrm{M}\right]$. a) and b): starting conditions of the real and the model system. c) and d): status of the system (observed and calculated) after 100 days using the flux scheme outlined in figure 17.

Abb. 18. Vergleich der simulierten und beobachteten Kupferkonzentrationen im Hypolimnion. a) und b): Anfangsbedingungen im wirklichen und im Modeilsystem. c) und d): Zustand des Systems (beobachtet und berechnet) nach 100 Tagen unter Verwendung des in Abb. 17 skizzierten Flußschemas. 
The transfer from $\mathrm{PCu}_{\mathrm{O}}$ to $\mathrm{DCu}$ is given by

$$
\mathrm{J}_{\mathrm{PO}}=\mathrm{K}_{2} \quad\left[\mathrm{PCu}_{\mathrm{o}}\right] \text {, }
$$

where $\mathrm{K}_{2}$ is chosen that approximately $50 \%$ of the particulate organic copper entering the hypolimnion is mineralized when it touches the sediment. The corresponding value is $0.05 \mathrm{~d}^{-1}$.

It is evident that

$$
\mathrm{J}_{\mathrm{D}}=-\left(\mathrm{J}_{\mathrm{PO}}+\mathrm{J}_{\mathrm{PFe}}\right) \text {. }
$$

The results of this simulation are compared with the observed values in figure 18 . The doubling of the copper content in the dissolved phase from June to September (fig. $18 \mathrm{a}$ and $\mathrm{c}$ ) and relatively constant concentration profile of the particulate copper in the same period (fig. $18 \mathrm{~b}$ and $\mathrm{d}$ ) can be explained by the proposed flux scheme.

It must be emphasized that only the combination of the two transport paths iron wheel' and 'mineralization of particulate organic material' can explain reasonably, i.e. within the range of physical and chemical parameters indicated by experimental data, the observed phenomena.

The anaerobic hypolimnion of Lake Baldegg can be considered as a large scale redox system which resembles analogous systems in the sediment/water interface having only a dimension of a few centimeters with an aerobic water column above. Therefore the proposed chemical mechanism may be also useful in the study of the latter systems.

\section{Summary}

Lake Baldegg, a meromictic and highly eutrophic lake in central Switzerland, was chosen to study the influence of a permanent anaerobic hypolimnion on the transport of copper and zinc.

An analysis of the seasonal variations of the dissolved and particulate concentrations of the two metals leads to the conclusion that a significant quantity of particulate copper is formed in the hypolimnion. Such a process is not observed for zinc.

A statistical evaluation of the sedimentation rates at the lake bottom indicates that there is a distinct difference between copper and zinc in a period of high organic production and stagnation. In contrast to copper zinc correlates well with organic carbon (table 2).

Observed differences are explained as follows:

a) Zinc is assimilated more strongly into planktonic particles than copper. Most particulate zinc reaching the sediment is of autochthonous origin.

b) As contrasted with zinc, copper is also sorbed on iron particles formed in the upper hypolimnion at the ' $\mathrm{Fe}^{3+} / \mathrm{Fe}^{2+}$ interface'. This process, which leads to an additional copper elimination by sedimentation could be supported by laboratory experiments (fig. 16). Within the observed period it contributed up to $50 \%$ of the total sedimentation of copper (table 3). 
A flux scheme (fig. 17) for the hypolimnic copper transport is quantified in a onedimensional diffusion model. The combination of the 'iron wheel' and the 'mineralization of epilimnic organic particles' can explain observed phenomena (fig. 18).

\section{ZUSAMMENFASSUNG}

Der Baldeggersee, ein meromiktischer und hocheutropher See, diente zur Untersuchung des Kupferund Zink transportes in einem permanent anaeroben Hypolimnion.

Die Analyse der zeitlichen Änderungen von gelösten und partikulären Konzentrationen der zwei Metalle führt zum Schluss, dass eine bedeutende Menge des partikulären Kupfers im Hypolimnion entsteht. Ein analoger Prozess für Zink ist nicht feststellbar.

Eine statistische Bewertung der Sedimentationsraten am Seegrund deutet darauf hin, dass sich Kupfer und Zink zur Stagnationszeit bei hoher organischer Produktion unterschiedlich verhalten. Im Gegensatz zu Kupfer korreliert Zink sehr gut mit dem organischen Kohlenstoff (Tab. 2).

Die beobachteten Unterschiede werden wie folgt erklärt:

a) Die Zinkassimilation durch das Plankton ist grösser als jene des Kupfers. Der grösste Teil des partikulären Zinks, das bis ins Sediment gelangt, wird im Epilimnion gebildet.

b) Im Gegensatz dazu erfährt Kupfer eine Adsorption an neu sich bildenden Partikeln in der $« \mathrm{Fe}^{3+}$ / $\mathrm{Fe}^{2+}-$ Grenzfläche» des oberen Hypolimnions. Ein solcher Fäilungsprozess, der zu einer zusätzlichen Kupferelimination im See führt, konnte ebenfalls in Laborexperimenten beobachtet (Abb.16) werden. In der beobachteten Periode trägt diese Fällung bis zu 50\% der gesamten Kupfersedimentation bei (Tab.3).

Der hypolimnische Kupfertransport wurde anhand eines Flußschemas (Abb.17) quantifiziert. Dazu diente ein eindimensionales Diffusionsmodell. Die Kombination eines «Eisenrads» mit der «Mineralisation organischer Partikeln aus dem Epilimnion» kann die beobachtete Kupferverteilung erklären (Abb. 18).

\section{RÉSUMÉ}

Le lac de Baldegg, un lac méromictique et très eutrophe, a été choisi pour étudier l'influence d'un hypolimnion permanentement anaérobe sur le transport de cuivre et de zinc.

Une analyse des variations saisonnières des concentrations des phases dissoutes et particulaires mène à la conclusion qu'une quantité significative de cuivre est formée dans l'hypolimnion. Un tel processus n'est pas observé pour le zinc.

Une évaluation statistique des flux de sédimentation au fond du lac indique qu'il y a une différence distincte entre le cuivre et le zinc pendant la période de stagnation et de forte production organique. Contrairement au cuivre le zinc corrèle bien avec le carbone organique (tabl.2).

Les différences observées sont expliquées comme suit:

a) Le zinc est assimilé plus fortement par le plancton que le cuivre. La plupart de zinc particulaire qui arrive au sédiment est d'origine autochthone.

b) Contrairement au zinc le cuivre est aussi adsorbé par des particules de fer formées à l'interface $\mathrm{Fe}^{3+} /$ $\mathrm{Fe}^{2+}$ dans l'hypolimnion supérieur. Un tel processus qui est responsable d'une élimination supplémentaire de cuivre, est aussi observé dans des essais de laboratoire (fig. 16). Dans la période observée cette précipitation contribue jusqu'à 50\% de la sédimentation totale de cuivre (tabl.3).

Pour le transport hypolimnique de cuivre un schéma de flux a été quantifié à l'aide d'un modèle de diffusion à une dimension (fig. 17). La combinaison de la uroue de fer» et la uminéralisation des particules organiques» peut expliquer les phénomènes observés (fig. 18).

\section{VERDANKUNG}

Wir danken Dres. R. Gächter, W. Schneider und W. Stumm für die wertvollen Vorschläge bei der Bearbeitung des Manuskriptes. H. Bolliger zeichnete die Figuren, A. Widmer und S. Graf schrieben das Manuskript. 


\section{REFERENCES}

1 Gächter, R., and Mares, A.: MELIMEX, an experimental heavy metal pollution study: Effects of increased heavy metal loads on phytoplankton communities. Schweiz. Z. Hydrol. 41, 228-246 (1979).

2 Gächter, R., and Baccini, P.: Wie stark dürfen Seen mit Schwermetallen belastet werden. Neue Zürcher Zeitung, Beilage Forschung und Technik, No.50, 1.3.1978.

3 Baccini, P.: Untersuchungen über den Schwermetallhaushalt in Seen. Schweiz. Z. Hydrol, 38, 121158 (1976).

4 Baccini, P., Ruchti, J., Wanner, O., and Grieder, E.: MELIMEX, an experimental heavy metal pollution study: Regulation of trace metal concentrations in limno-corrals. Schweiz. Z. Hydrol. 4l, 202-227 (1979).

5 Strickland, J.D.H., and Parsons, T.R.: A Practical Handbook of Seawater Analysis. Fish. Res. Bd Can., Bull. 167 (1968).

6 Stadelmann, P.: Stickstoffkreislauf und Primärproduktion im mesotrophen Vierwaldstättersee und im eutrophen Rotsee, mit besonderer Berücksichtigung des Nitrats als limitierender Faktor. Schweiz. Z. Hydrol. 33, 1-65 (1971).

7 Bossard, P., and Joller, Th.: Die quantitative Erfassung von Methan im Seewasser. Schweiz. Z. Hydrol., in preparation.

8 Emerson, S., Coranston, R.E., and Liss, P.S.: Redox species in a reducing fjord: equilibrium and kinetic considerations. Deep-Sea Res. 26A, 859-878 (1979).

9 Hydrologisches Jahrbuch der Schweiz 1977. Eidg. Drucksachen- und Materialzentrale, Bern.

10 Huber-Pestalozzi, G.: Das Phytoplankton des Süsswassers, parts 1-5. In: Die Binnengewässer, vol. 16. E. Schweizerbartsche Verlagshandlung.

11 Schiess, Th.: Limnologisch-biologischer Bericht über den Baldeggersee 1974/75. Schweiz. Bund für Naturschutz, Basel 1976.

12 Baccini, P., and Suter, U.: Chemical speciation and biological availability of copper in lake water. Schweiz. Z. Hydrol. 41, 291-314 (1979).

13 Baccini, P., unpublished results.

14 Burns, N.M., and Resa, F.: In situ measurement of the settling velocity of organic particles and 10 species of phytoplankton. Limnol. Oceanogr. 25/5, 855-864 (1980).

15 Joller, Th.: Thesis ETH Zürich, in preparation.

16 Schneider, W.: ETH Zürich, personal communication.

17 Theis, Th. L., and Singer, P.C.: The stabilization of organic compounds in natural waters. In: Trace metals and metalorganic interactions in natural waters. Ed. P.C. Singer. Ann Arbor Science, 1973.

18 Campbell, P., and Torgersen, T.: Maintenance of iron meromixis by iron redeposition in a rapidly flushed monimolimnion. Can. J. Fish. Aquat. Sci. 37, 1303-1313 (1980).

19 Davison, W., Heany, S.I., Talling, J.F., and Rigg, E.: Seasonal transformations and movements of iron in a productive English lake with deep water anocia. Schweiz. Z. Hydrol. 42/2, 196-224 (1980).

Address of the authors: Dr.P. Baccini, T. Joller, Seenforschungslaboratorium der EAWAG/ETH, CH6047 Kastanienbaum, Switzerland. 